\title{
KANDUNGAN KAROTENOID, ANTIOKSIDAN, DAN KADAR AIR DUA VARIETAS CABAI RAWIT PADA TINGKAT KEMATANGAN BERBEDA DAN DETEKSI NON-DESTRUKTIF
}

\section{CAROTENOIDS, ANTIOXIDANTS, AND WATER CONTENTS OF TWO CAYENNE PEPPER VARIETIES AT DIFFERENT MATURITY LEVELS AND NON-DESTRUCTIVE DETECTION}

\author{
Kusumiyati ${ }^{*}$, Ine Elisa Putri, Wawan Sutari, Jajang Sauman Hamdani \\ Program Studi Agronomi, Fakultas Pertanian, Universitas Padjadjaran \\ Jl. Raya Bandung-Sumedang KM. 21-45363, Jawa Barat, Indonesia \\ *Korespondensi: kusumiyati@unpad.ac.id
}

Diterima : 22 November 2021/ Disetujui: 15 Desember 2021

\begin{abstract}
ABSTRAK
Cabe rawit umumnya berwarna hijau, jingga dan merah. Tiap tingkat kematangan memiliki kualitas yang berbeda. Teknologi non-destruktif visible/near infrared spectroscopy (Vis/NIRS) telah banyak digunakan untuk memprediksi kualitas secara cepat dan akurat serta tidak merusak. Penelitian bertujuan untuk mengetahui kandungan kadar air, total karotenoid dan antioksidan dua varietas buah cabai rawit dengan tingkat kematangan berbeda dan memprediksi kualitas secara non-destruktif menggunakan Vis/NIRS. Penelitian dilakukan di Laboratorium Hortikultura, Fakultas Pertanian, Universitas Padjadjaran. Penelitian disusun dalam rancangan acak lengkap (RAL) dengan 6 perlakuan yaitu varietas 'Manik' dan 'Domba', yang dipanen pada 20 hari setelah bunga mekar (HSBM), 40 HSBM dan 60 HSBM, serta diulang 5 kali. Data dianalisis dengan analisis varians (ANOVA). Hasil penelitian menunjukkan bahwa varietas 'Manik' and 'Domba' yang dipanen pada 20 HSBM memiliki kandungan kadar air dan antioksidan tertinggi sedangkan total karotenoid meningkat pada buah matang. Model kalibrasi dan uji validasi silang kadar air, total karotenoid, dan antioksidan mendapatkan nilai $R_{\text {kal }} \geq 0,87$ dan $R_{\text {val }} \geq 0,84$. Berdasarkan hasil tersebut, maka kandungan air dan antioksidan terbesar yaitu buah cabai rawit hijau sedangkan total karotenoid tertinggi pada buah cabai rawit merah. Vis/NIRS dapat digunakan untuk mendeteksi kandungan air, total karotenoid dan antioksidan pada buah cabai rawit.
\end{abstract}

Kata kunci: Analisis kimia, Antioksidan, Fitokimia, Kualitas buah, Radikal bebas

\begin{abstract}
Generally, cayenne pepper is coloring in green, orange, and red. Each maturity level has a different quality. A non-destructive technology, visible/near infrared spectroscopy (Vis/NIRS), has been widely used to predict the quality quickly and accurately without causing damage. The study aimed to determine water content, total carotenoids, and antioxidant of two varieties cayenne pepper with different maturity levels and to predict quality non-destructively using Vis/NIRS. The research was conducted at the Horticulture Laboratory, Agriculture Faculty, Universitas Padjadjaran. The research was arranged in a completely randomized design (CRD) with 6 treatments, namely 'Manik' and 'Domba' varieties harvested at 20 days after flowering (DAF), $40 \mathrm{DAF}$ and $60 \mathrm{DAF}$, and 5 replications with analysis of variance

Cite this as: Kusumiyati, Putri, I. E., Sutari, W., \& Hamdani, J. S. (2021). Kandungan karotenoid, antioksidan, dan kadar air dua varietas cabai rawit pada tingkat kematangan berbeda dan deteksi non-destruktif. Jurnal Agro, 8(2), 212-225. https://doi.org/10.15575/14650
\end{abstract}


(ANOVA). The results showed that 'Manik' and 'Domba' harvested at 20 DAF had the highest water content and antioxidant while the total carotenoids increased in ripe fruit. The calibration model and cross-validation of water content, total carotenoids, and antioxidants obtained values of $R_{\text {cal }} 0.87$ and $R_{\text {val }} 0.84$. Based on these results, the highest water and antioxidant content was green cayenne pepper, while the highest total carotenoids were in red cayenne pepper. Vis/NIRS can be used to detect water content, total carotenoids, and antioxidants in cayenne pepper.

Key words : Antioxidants, Chemical analysis, Free radicals, Fruit quality, Phytochemicals

\section{PENDAHULUAN}

Kualitas pada produk hortikultura merupakan penentu penerimaan konsumen. Buah cabai rawit yang beredar di pasaran biasanya terbagi dalam beberapa warna kulit buah yaitu hijau, jingga serta merah. Kualitas buah cabai rawit berbeda pada masing-masing varietas dan tingkat kematangan, sehingga teknik budidaya, panen dan pascapanen merupakan proses yang panjang dalam menghasilkan dan menjaga produk agar tetap berkualitas. Terdapat beberapa varietas yang telah ditanam di Indonesia, diantaranya yaitu buah cabai rawit varietas 'Domba' dan 'Manik'. Secara visual, Kedua varietas tersebut memiliki karakteristik fisik yang sangat berbeda. Buah cabai rawit varietas 'Domba' memiliki ukuran yang lebih besar dibandingkan buah cabai rawit 'Manik'. Buah cabai rawit 'Domba' mempunyai panjang hingga $\pm 55 \mathrm{~mm}$ sedangkan buah cabai rawit 'Manik' memiliki panjang \pm 25 $\mathrm{mm}$. Buah cabai rawit 'Domba' muda berwarna hijau muda dan buah cabai rawit 'Manik' muda berwarna hijau tua.

Penampilan luar dari buah cabai rawit menjadi indikator kualitas pada buah cabai rawit. Kriteria kualitas yang paling mudah dilihat yaitu berupa diameter, panjang, bobot dan warna kulit buah. Meskipun begitu penampilan luar tidak selalu berbanding lurus dengan kandungan yang terdapat di dalam buah. Selain penampilan luar, kadar air juga dapat memengaruhi penampilan buah. Hal ini karena kadar air menjadi penentu kesegaran buah dan waktu simpan. Kadar air merupakan penentu umur simpan suatu produk, kadar air yang tinggi akan menyebabkan produk pertanian semakin rentan dan daya simpan cenderung tidak lama (Amanto et al., 2015).

Buah cabai rawit memiliki kandungan metabolit sekunder yang bermanfaat bagi kesehatan tubuh manusia seperti antioksidan dan karotenoid. Kandungan tersebut dapat meningkatkan imunitas. Kandungan antioksidan buah cabai rawit ditentukan oleh varietas dan tingkat kematangannya. Senyawa antioksidan adalah kumpulan dari senyawa-senyawa yang dapat menghambat reaksi dari oksidasi, menangkal radikal bebas dengan cara mengikat atom-atom radikal bebas yang merupakan atom dengan elektron yang tidak berpasangan. Antioksidan terdiri dari berbagai senyawa yang dapat digunakan sebagai penghambat dan menetralisir pada saat terjadi reaksi oksidasi yang melibatkan radikal-radikal bebas (Hamed et al., 2019). Senyawa antioksidan yang terkandung di dalam buah cabai rawit diantaranya yaitu vitamin C, karotenoid dan capsaicin (Sun et al., 2007; Zimmer et al., 2012).

Kandungan buah cabai rawit biasanya dapat diketahui dari pengujian secara destruktif. Teknologi pengujian secara 
destruktif adalah pengujian yang dilakukan dengan cara mengubah sampel menjadi berbagai bentuk materi namun sampel menjadi rusak. Pengujian untuk mengetahui nilai kadar air dapat dilakukan dengan menggunakan metode gravimetri. Pengujian total karotenoid menggunakan metode spektrofotometri. Pengujian kandungan antioksidan dilakukan dalam skala laboratorium dengan metode 2,2difenil 1-1 picrylhidrazyl (DPPH). Nilai kandungan antioksidan secara kuantitatif dinyatakan dalam aktivitas dan kapasitas antioksidan.

Pengujian secara destruktif menyebabkan buah rusak dan tidak dapat dijual. Selain itu, pengujian di laboratorium membutuhkan biaya, tenaga serta waktu yang tidak sedikit sehingga kurang efisien. Solusi agar pengujian kualitas buah dapat dilakukan tanpa merusak yaitu dengan pengujian secara non-destruktif. Teknologi ini dapat memprediksi kualitas buah secara kuantitatif, cepat, tepat, dan efisien serta buah dapat dijual kembali. Salah satu teknologi non-destruktif yang dapat digunakan adalah visible/near infrared spectroscopy (Vis-NIRS).

Peneliti ataupun pelaku industri sudah banyak yang menerapkan teknologi nondestrukstif untuk memprediksi kualitas berbagai produk. Teknologi Vis-NIRS dapat digunakan untuk memprediksi kualitas buah secara non-destruktif, sehingga pemanfaatannya dapat digunakan untuk grading dan monitoring kualitas buah. Prediksi kualitas dapat dilakukan setelah terlebih dahulu memasukkan model kalibrasi untuk komoditas dan parameter yang akan diujikan pada alat spectrometer. Model kalibrasi berbeda dengan pengertian kalibrasi alat. Model kalibrasi merupakan model yang dibangun berdasarkan korelasi antara variabel $\mathrm{X}$ (spektra Vis/NIRS) dari sampel dengan variabel $Y$ (data aktual parameter uji). Model ini memperkirakan antara berbagai variabel bebas (spektra) dan variabel terikat (data aktual/hasil destruksi laboratorium), sehingga model ini dapat dipergunakan berulang secara akurat sedangkan kalibrasi alat yaitu memverifikasi kesesuaian alat agar tetap akurat dan presisi.

Teknologi Vis/NIRS telah digunakan pada berbagai kualitas pada buah-buahan diantaranya menguji kadar air buah cabai rawit (Kusumiyati et al., 2021b; Putri et al., 2021), kadar asam pada buah stroberi (Shao \& He, 2008), kadar air sawo (Kusumiyati et al., 2018), kadar asam dan total padatan terlarut (TPT) buah mangga dan buah jambu batu (Kusumiyati et al., 2020; Munawar et al., 2013), asam askorbat buah markisa (Alamar et al., 2016) dan TPT berbagai famili Cucurbitaceae dan melon (Hadiwijaya et al., 2020a, 2020b; Kusumiyati et al., 2021a; Kusumiyati et al., 2021). Namun, belum ada yang menguji kandungan buah cabai rawit varietas 'Manik' dan 'Domba' pada berbagai tingkat kematangan dan menguji kemampuan penggunaan Vis/NIRS untuk memprediksi kandungan buah cabai rawit. Berdasarkan uraian tersebut di atas, maka perlu diketahui kandungan air, total karotenoid, aktivitas dan kapasitas antioksidan pada berbagai varietas buah cabai rawit pada tingkat kematangan yang berbeda dan menguji keakuratan penggunaan Vis/NIRS untuk mendeteksi kandungan air, total karotenoid, aktivitas dan kapasitas antioksidan pada buah cabai rawit berbagai tingkat kematangan. 


\section{BAHAN DAN METODE}

\section{Penanaman cabai rawit untuk sampel}

Pada tahap awal budidaya dilakukan penyemaian benih cabai rawit. Benih yang disemai terlebih dahulu diseleksi dengan cara direndam air selama \pm 30 menit. Benih yang tenggelam selanjutnya ditanam. Benih cabai rawit disemai dalam potray yang diberi media arang sekam dan kompos (1:1). Setiap lubang potray berisikan 1 benih. Proses pindah tanam dilakukan setelah muncul 4-6 helai daun dan dipindah tanamkan dari persemaian ke lahan. Jarak tanam yang dipergunakan yaitu $40 \mathrm{~cm} \times 40$ $\mathrm{cm}$. Pupuk Mutiara 16:16:16 diberikan 2 minggu setelah tanam (MST). Pemupukan diberikan setiap 2 minggu sekali. Penyiraman disesuaikan dengan intensitas curah hujan. Pengendalian organisme penggangu tanaman (OPT) dilakukan dengan pengaplikasian fungisida dan pestisida sesuai dengan serangan yang muncul. Pemanenan buah cabai rawit pada varietas 'Manik' dan 'Domba' disesuaikan dengan umur panennya yaitu 20 hari setelah bunga mekar (HSBM), 40 HSBM dan 60 HSBM. Pengambilan sampel untuk analisis dilakukan pada periode panen ke-2.

\section{Sampel buah cabai rawit}

Terdapat 6 kombinasi jenis sampel yang terdiri dari 5 ulangan, sehingga terdapat 30unit percobaan. Kombinasi jenis sampel terdiri atas cabai rawit varietas 'Manik' and 'Domba', masing-masing dipanen pada 20 HSBM (hijau), 40 HSBM (jingga) dan 60 HSBM (merah). Masing - masing unit percobaan terdiri atas tiga sampel sehingga total terdapat 90 sampel. Analisis laboratorium dilaksanakan di Laboratorium Hortikultura, Departemen Budidaya Pertanian, Fakultas Pertanian, Universitas
Padjadjaran. Masing-masing unit sampel merupakan gabungan beberapa buah dengan total bobot $\pm 30 \mathrm{~g}$.

\section{Pengambilan data spektra Vis/NIRS}

Tiap satu unit sampel buah cabai rawit dimasukkan ke dalam Petridish untuk dilakukan pengambilan data spektra sebanyak 5 kali menggunakan portable Vis/NIR spectrometer (NirVana AG410). Panjang gelombang yang digunakan yaitu 312-1050 nm dan interval $3 \mathrm{~nm}$. Data spektra yang didapatkan dihitung nilai ratarata per unit sampelnya. Spektra original adalah hasil akuisisi yang berasal dari data absorban. Langkah berikutnya yaitu dilakukan pengukuran secara destruktif untuk parameter kadar air, total karotenoid, aktivitas dan kapasitas antioksidan.

\section{Analisis destruksi buah cabai rawit kadar air \\ Tiap unit sampel ditimbang} menggunakan timbangan analitik (Mettler Toledo AG245). Sampel yang digunakan sebanyak 2-3 g dipotong kecil-kecil lalu dimasukan ke dalam aluminium foil dan dikeringkan dalam oven (Memmert Schutzart Din 40050-IP 20, Germany) dengan suhu $105^{\circ} \mathrm{C}$. Pengeringan dalam oven bertujuan untuk mempercepat proses pengeluaran air yang terkandung di dalam sampel dengan cara penguapan yang disebabkan pemanasan. Berat sampel ditimbang secara berkala setiap 3 jam hingga didapatkan berat kering yang konstan (AOAC, 1995; Standarisasi Nasional Indonesia, 2019). Pengujian kadar air dilakukan dengan menggunakan metode gravimetri. Perhitungan kadar air yaitu:

$\%$ Kadar air: $\frac{\text { Berat basah }(\mathrm{g})-\text { berat kering }(\mathrm{g})}{\operatorname{Berat} \operatorname{Basah}(\mathrm{g})} \times 100 \%$ 


\section{Total karotenoid}

Total karotenoid diukur melalui tahap ekstraksi sampel menggunakan asetonitril. Ekstrak sampel diukur dengan spektrofotometer UV-Vis (Shimadzu UV mini-1240, Japan), standar yang digunakan yaitu $\beta$-Carotene. Hasil ekstraksi dimasukkan ke dalam kuvet dan diukur pada panjang gelombang $450 \mathrm{~nm}$ (Biswas et al., 2011; Pinheiro-santana et al., 1998). Kadar total karotenoid dihitung ke dalam persamaan garis regresi linear dan satuan akhir yang dinyatakan dalam $\mathrm{mg} 100 \mathrm{~g}^{-1}$.

\section{Antioksidan}

Tahapan ekstraksi sampel untuk pengukuran antioksidan menggunakan metanol. Pengukuran antioksidan metode DPPH diukur dengan spektrofotometer UVVis Shimadzu UV mini-1240, Japan. Aktivitas antioksidan dinyatakan dalam nilai inhibition concentration $50 \% \quad\left(I C_{50}\right) . \quad I C_{50}$ didapatkan dari hubungan antara \% inhibisi dan konsentrasi larutan masing-masing sampel. Ascorbic acid (Vitamin C) digunakan sebagai standar dan hasil pengukuran dinyatakan sebagai ascorbic acid equivalent antioxidant capacity (AEAC) dalam mg AA $100 \mathrm{~g}^{-1}$ (Lim \& Murtijaya, 2007).

\section{Analisis data}

Analisis yang digunakan pada penelitian ini adalah analisis varians (Anova) dengan rancangan acak lengkap (RAL) dengan Uji Lanjut Jarak Berganda Duncan $5 \%$ dan diolah menggunakan SPSS 24. Analisis multivariat digunakan untuk memperoleh model kalibrasi dan uji validasi silang. Analisis multivariat menggunakan The Unscrambler 10.4. Model kalibrasi dibangun dengan melibatkan variabel prediktor (spektra) dan variabel respon (hasil data aktual destruksi). Model kalibrasi dan uji validasi silang menggunakan 60 sampel, hasil seleksi dari total 90 sampel.

Uji validasi ditujukan untuk dapat menguji model kalibrasi yang didapatkan menggunakan uji validasi silang (cross validation) dengan menggunakan sampel yang sama. Model kalibrasi dan uji validasi silang dipergunakan untuk mengevaluasi tingkat keakuratan model. Tingkat keakuratan model kalibrasi partial least square regression (PLSR) dan uji validasi dilihat dari nilai korelasi (R), root mean square error of calibration (RMSEC) atau root mean square error of cross validation (RMSECV), standar deviasi (SD), ratio of performance to deviation (RPD) dan principal component (PC).

\section{HASIL DAN PEMBAHASAN}

Pada Tabel 1 menampilkan besaran kadar air, total karotenoid, aktivitas dan kapasitas antioksidan atau ascorbic acid equivalent antioxidant capacity (AEAC) pada berbagai varietas buah cabai rawit pada tingkat kematangan berbeda. Kadar air pada masing - masing varietas mengalami penurunan pada tingkat kematangan yang semakin lanjut. Kadar air 'Domba' tertinggi berada pada 20 HSBM yang berbeda nyata dengan perlakuan lainnya yaitu $73,28 \%$ sedangkan 'Domba' 40 HSBM yaitu 69,38\% dan 60 HSBM 67,08\% terjadi penurunan walalupun tidak saling berbeda nyata. Varietas 'Manik' mempunyai kadar air tertinggi pada 'Manik' 20 HSBM yaitu $72,02 \%$ dan berbeda nyata dengan 'Manik' 40 HSBM 60,09\% dan 'Manik' 60 HSBM 59,24\%. Secara keseluruhan, kadar air tertinggi dimiliki oleh 'Domba' 20 HSBM yang tidak berbeda nyata dengan 'Manik' 20 HSBM dan kadar air terkecil yaitu 'Manik' 
40 HSBM dan 'Manik' 60 HSBM. Hasil tersebut sejalan dengan penelitian yang dilakukan oleh Khairiah et al. (2019) yang menyatakan bahwa kadar air 'Domba' mengalami penurunan pada saat semakin matang yaitu dari $79,82 \%$ menjadi $61,69 \%$ dan hal ini disebabkan oleh aktivitas transpirasi, sehingga menyebabkan buah cabai menjadi keriput dan terjadi penurunan kesegaran buah cabai. Sejalan dengan penelitian dari Getahun et al. (2020) dan Li et al. (2009) yang menyatakan bahwa kadar air cabai hijau lebih besar dari pada cabai merah. Proses pematangan buah mengakibatkan perubahan metabolisme yang berakhir dengan akumulasi maksimum bahan kering dan ditandai dengan perubahan biokimia, fisik, morfologi dan fisiologis, termasuk kadar air (Dos Santos et al., 2020). Tiap genotip yang berbeda akan menghasilkan respon yang berbeda pula pada parameter kualitas yang diamati. Hal ini dikarenakan tiap varietas memiliki kekhasan masing-masing. Pada penelitian yang telah dilakukan oleh Wulananggraeni et al. (2016) disimpulkan bahwa tiap genotip akan memberikan respon yang berbeda-beda pada masing-masing tingkat kematangan.

Pada Tabel 1 menunjukkan bahwa total karotenoid berbeda nyata pada dua varietas dengan berbagai tingkat kematangan. Secara keseluruhan, total karotenoid terkecil 'Domba' 20 HSBM yaitu 9,47 mg $100 \mathrm{~g}^{-1}$ yang tidak berbeda nyata dengan 'Domba' 40 HSBM dan 'Manik' 20 HSBM sedangkan yang terbesar yaitu 'Manik' 60 HSBM dengan 402,80 mg $100 \mathrm{~g}^{-1}$. Pada masing- masing varietas 'Domba' dan 'Manik' mengindikasikan kenaikan total karotenoid pada saat semakin matang. Klorofil bertanggung jawab untuk warna hijau pada buah cabai, total karotenoid mengontrol warna merah dan kandungan total karotenoid pada buah cabai merah matang dapat meningkat 2 - 60 kali lipat dibandingkan dengan buah yang belum matang (Gómez-García et al., 2013).

Tabel 1. Kualitas dua varietas buah cabai rawit pada berbagai tingkat kematangan

\begin{tabular}{lccccc}
\hline No & Jenis cabai rawit & $\begin{array}{c}\text { Kadar air } \\
(\%)\end{array}$ & $\begin{array}{c}\text { Total } \\
\text { karotenoid } \\
\left(\mathrm{mg} \mathrm{100} \mathrm{g}^{-1}\right)\end{array}$ & $\begin{array}{c}\text { Aktivitas } \\
\text { antioksidan } \\
(\mathrm{ppm})\end{array}$ & $\begin{array}{c}\text { Kapasitas } \\
\text { antioksidan } \\
\left(\mathrm{mg} \mathrm{AA} \mathrm{100} \mathrm{g}^{-1}\right)\end{array}$ \\
\hline 1 & 'Domba' 20 HSBM & $73,28 \mathrm{~d}$ & $9,47 \mathrm{a}$ & $1878,93 \mathrm{a}$ & $173,69 \mathrm{~d}$ \\
2 & 'Domba' 40 HSBM & $69,38 \mathrm{bc}$ & $47,38 \mathrm{ab}$ & $2944,46 \mathrm{~b}$ & $110,67 \mathrm{a}$ \\
3 & 'Domba' 60 HSBM & $67,08 \mathrm{~b}$ & $118,67 \mathrm{c}$ & $2838,73 \mathrm{~b}$ & $118,28 \mathrm{ab}$ \\
4 & 'Manik' 20 HSBM & $72,02 \mathrm{~cd}$ & $38,78 \mathrm{ab}$ & $1820,66 \mathrm{a}$ & $173,94 \mathrm{~d}$ \\
5 & 'Manik' 40 HSBM & $60,09 \mathrm{a}$ & $78,09 \mathrm{bc}$ & $2095,13 \mathrm{a}$ & $150,40 \mathrm{c}$ \\
6 & 'Manik' 60 HSBM & $59,24 \mathrm{a}$ & $402,80 \mathrm{~d}$ & $2577,20 \mathrm{~b}$ & $130,47 \mathrm{~b}$ \\
\hline
\end{tabular}

Keterangan: Nilai dengan rata-rata yang diakhiri huruf dan kolom yang sama mengindikasikan tidak berbeda nyata berdasarkan Uji Lanjut Jarak Berganda Duncan 5\%.

Pada masing-masing varietas, 'Domba' 20 HSBM dan 'Domba' 40 HSBM memiliki nilai total karotenoid yaitu $9,47 \mathrm{mg} 100 \mathrm{~g}^{-1}$ dan 47,38 $\mathrm{mg} 100 \mathrm{~g}^{-1}$ tidak saling berbeda nyata. Di sisi lain, 'Domba' 60 HSBM berbeda nyata dengan 'Domba' 20 HSBM dan 40 HSBM dengan nilai tertingginya yaitu
$118,67 \mathrm{mg} 100 \mathrm{~g}^{-1}$. Pada varietas 'Manik' juga menunjukkan 'Manik' 20 HSBM dan 'Manik' 40 HSBM saling tidak berbeda nyata namun berbeda nyata dengan 'Manik' 60 HSBM yang mempunyai nilai total karotenoid terbesar yaitu 402,80 mg $100 \mathrm{~g}^{-}$ 1. Penelitian lainnya menyebutkan bahwa 
buah cabai rawit varietas Tobasco dan mutan G1/M13 pada berbagai tingkat kematangan memiliki kadar total karotenoid yang berkisar antara $28,2 \mathrm{mg}$ $100 \mathrm{~g}^{-1}$ - 332,3 mg $100 \mathrm{~g}^{-1}$ (Rahmatullah, 2018; Wall et al., 2001).

Aktivitas antioksidan diketahui dari nilai $I_{50}$. Nilai dari $I_{50}$ berbanding terbalik dengan kandungan antioksidan. Suatu bahan yang memiliki nilai $\mathrm{IC}_{50}$ yang kecil mengindikasikan bahwa bahan tersebut mempunyai kandungan antioksidan yang besar, karena $\mathrm{IC}_{50}$ mewakili konsentrasi sampel yang diperlukan untuk dapat mengurangi 50\% absorbansi dari larutan DPPH yang dapat tereduksi (Rusmana et al., 2017; Sil \& SimHan, 2008).

Nilai aktivitas antioksidan buah cabai rawit 'Domba' dan 'Manik' pada berbagai tingkat kematangan berbeda nyata. Nilai $I_{50}$ terkecil yaitu 'Domba' 20 HSBM, 'Manik' 20 HSBM dan 'Manik' 40 HSBM, walaupun demikian hal ini menunjukkan bahwa ketiganya memiliki kandungan antioksidan yang tinggi dibandingkan dengan 'Domba' 40 HSBM, 'Domba' 60 HSBM, dan 'Manik' 60 HSBM. Pada tiap varietas mengindikasikan bahwa antioksidannya menurun saat buah semakin matang. Antioksidan pada buah cabai berkaitan dengan kandungan capsaicin, dihydrocapsaicin, karotenoid, vitamin C, fenol, flavonoid (Hamed et al., 2019).

Kapasitas antioksidan tertinggi dimiliki oleh 'Domba' 20 HSBM (173,69 mg AA 100 $\left.\mathrm{g}^{-1}\right)$ dan 'Manik' 20 HSBM (173,94 mg AA $100 \mathrm{~g}^{-1}$ ) sedangkan terendah yaitu 'Domba' $40 \operatorname{HSBM}\left(110,67 \mathrm{mg}\right.$ AA $\left.100 \mathrm{~g}^{-1}\right)$ yang tidak berbeda nyata dengan 'Domba' 60 HSBM. Pada 'Domba', tingkat kematangan 20 HSBM memiliki kapasitas antioksidan tertinggi dan mengalami penurunan pada kematangan berikutnya. 'Domba' 40 HSBM dan 'Domba' 60 HSBM tidak saling berbeda nyata. Hasil menunjukkan bahwa, varietas 'Manik' mengindikasikan perbedaan yang nyata pada nilai kapasitas antioksidan untuk setiap tingkat kematangan. Kapasitas antioksidan tertinggi hingga terendah pada 'Manik' yaitu 20 HSBM, 40 HSBM dan 60 HSBM, nilainya masing-masing 173,94 ; 150,40 dan 130,47 ppm.

Nilai kapasitas antioksidan yang tinggi menandakan semakin tinggi kandungan senyawa antioksidan yang terkandung di dalam sampel. Kadar antioksidan dipengaruhi oleh genotip, tingkat kematangan, bagian tanaman yang dikonsumsi, kondisi selama pertumbuhan dan penanganan pasca panen (Deepa et al., 2007).

Pada penelitian ini, buah cabai rawit yang semakin matang memiliki aktivitas antioksidan dan kapasitas antioksidannya yang semakin kecil. Hal ini sejalan dengan penelitian yang dilakukan oleh CastroConcha et al. (2014) bahwa pada buah Capsicum chinense Habanero yang semakin matang akan memiliki nilai $\mathrm{IC}_{50}$ semakin besar (aktivitas antioksidan kecil) dan kapasitas antioksidannya semakin kecil. Nilai I $C_{50}$ yang semakin rendah dan semakin tinggi nilai AEAC, maka semakin besar antioksidannya (Lai and Lim, 2011).

Vis/NIRS merupakan salah satu metode non-destruktif yang telah lama digunakan sebagai metode untuk memprediksi atau mendeteksi kualitas berbagai buah. Teknologi spectroscopy juga telah digunakan pada buah alpukat (Olarewaju et al., 2016), buah tomat (Huang et al., 2018), buah apel (Fan et al., 2020) dan buah stroberi (Sánchez et al., 2012). Teknologi ini dianggap ramah lingkungan serta dapat mengefisiensikan waktu, tenaga serta biaya. Sinar yang dipancarkan dari detektor pada 
dasarnya akan dipantulkan, diserap dan diteruskan jika mengenai sebuah objek. Suatu bahan yang terkena radiasi sinar akan menyebabkan atom-atom bergetar. Cahaya setelah mengenai suatu bahan akan dipantulkan kembali atau diserap. Spektra dari cahaya akan berinteraksi dengan kandungan kimia suatu produk. Kandungan kimia terbaca oleh berbagai puncak dan lembah spektra. Puncak dan lembah yang muncul terjadi karena getaran pada atom dalam molekul di antaranya berbagai ikatan atom hidrogen seperti $\mathrm{C}-\mathrm{H}, \mathrm{O}-\mathrm{H}$, dan $\mathrm{N}-\mathrm{H}$ yang dapat memberikan informasi mengenai kandungan kimia (Masdar et al., 2016; Sari et al., 2016).

Pada Tabel 2 memperlihatkan hasil model kalibrasi dan uji validasi silang kadar air, total karotenoid, aktivitas dan kapasitas antioksidan dua varietas cabai rawit pada berbagai tingkat kematangan. Pada model kalibrasi untuk pendugaan nilai kadar air diperoleh bahwa model yang dibangun dengan menggunakan metode koreksi orthogonal signal correction (OSC) menghasilkan model kalibrasi dengan akurasi tertinggi jika dibandingkan dengan original. Model kalibrasi dan uji validasi silang yang diperoleh OSC yaitu $R_{\text {kal }} 0,99$, RMSEC 0,28, R Rv $_{\text {0 }}$, 97, RMSECV 1,48 dan RPD 4,75. Nilai $R$ menggambarkan seberapa besar kemampuan semua variabel bebas untuk dapat menjelaskan variasi pada variabel terikatnya. Nilai $R_{\text {kal }}$ yang didapatkan sebesar 0,99, hal ini dapat diartikan bahwa sebanyak $99 \%$ dari data keseluruhan variabel terikat dapat dijelaskan oleh variabel bebasnya. Kuat atau lemahnya hubungan antara dua variabel $X$ dan $Y$ dinyatakan dalam fungsi linear dan dilihat dari nilai koefisien korelasinya (Paiman, 2019). Selain nilai R yang dijadikan penentu keakuratan suatu model kalibrasi, nilai RPD juga menjadi penting untuk diperhitungkan dalam membuat model kalibrasi. Sebaran data model kalibrasi dan uji validasi silang nilai kadar air terlihat pada Gambar 1.

Tabel 2. Model kalibrasi dan validasi silang kualitas buah cabai rawit

\begin{tabular}{llllllll}
\hline Parameter & $\begin{array}{l}\text { Metode } \\
\text { koreksi }\end{array}$ & $\mathrm{PC}$ & $\mathrm{R}_{\text {kal }}$ & RMSEC & $\mathrm{R}_{\text {val }}$ & RMSECV & RPD \\
\hline \multirow{2}{*}{ Kadar air } & Original & 10 & 0,85 & 3,61 & 0,76 & 4,65 & 1,51 \\
Total karotenoid & OSC & 10 & 0,99 & 0,28 & 0,97 & 1,48 & 4,75 \\
& Original & 3 & 0,73 & 102,55 & 0,69 & 110,88 & 1,38 \\
Aktivitas antioksidan & OSC & 13 & 0,99 & 3,54 & 0,97 & 29,24 & 5,26 \\
& Original & 3 & 0,87 & 283,62 & 0,84 & 312,04 & 1,90 \\
& OSC & 3 & 0,87 & 278,34 & 0,84 & 310,11 & 1,91 \\
Kapasitas antioksidan & Original & 1 & 0,67 & 24,60 & 0,63 & 26,06 & 1,28 \\
& OSC & 17 & 0,99 & 0,26 & 0,98 & 5,22 & 6,41 \\
\hline
\end{tabular}

PC: princpal components, Rkal: nilai korelasi kalibrasi, Rval: nilai korelasi validasi, RMSEC: root mean square error of calibration, RMSECV: root mean square error of cross validation, RPD: ratio of performance to deviation 


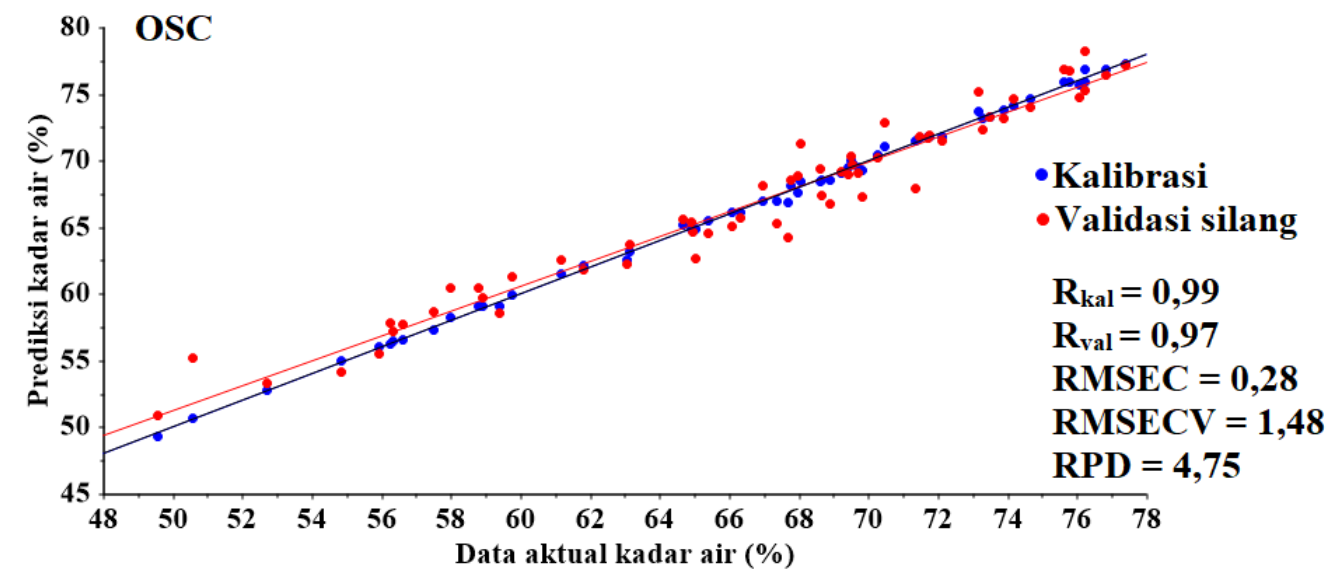

Gambar 1. Scatter plot kalibrasi dan validasi silang kadar air: OSC

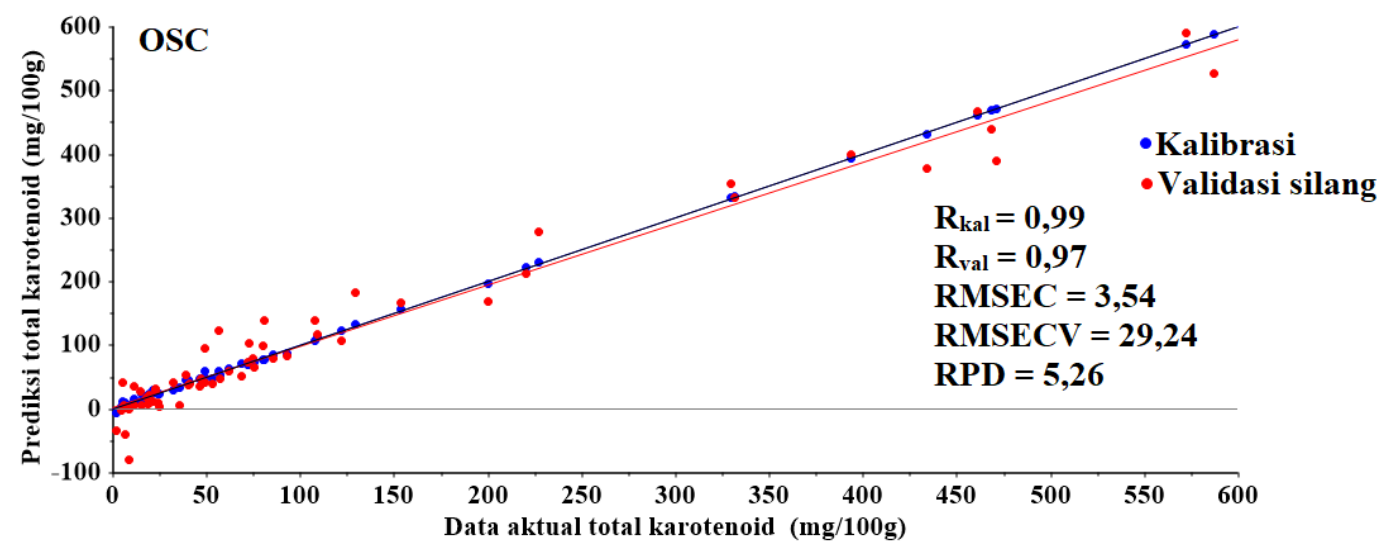

Gambar 2. Scatter plot kalibrasi dan validasi silang total karotenoid: OSC

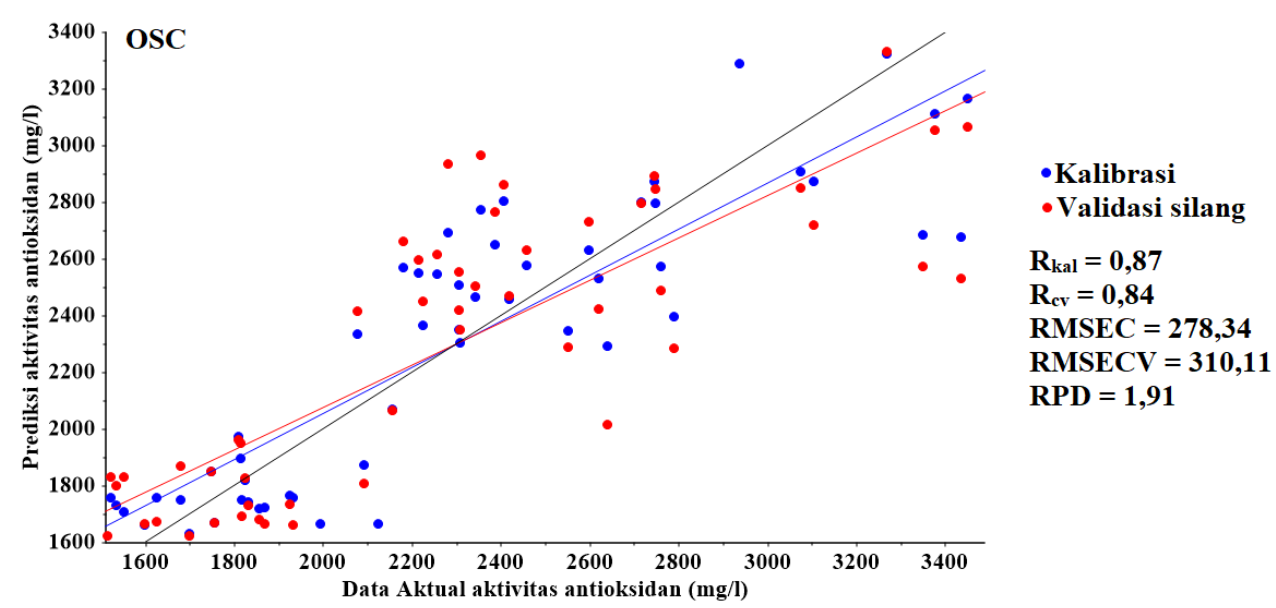

Gambar 3. Scatter plot kalibrasi dan validasi silang aktivitas antioksidan: OSC 


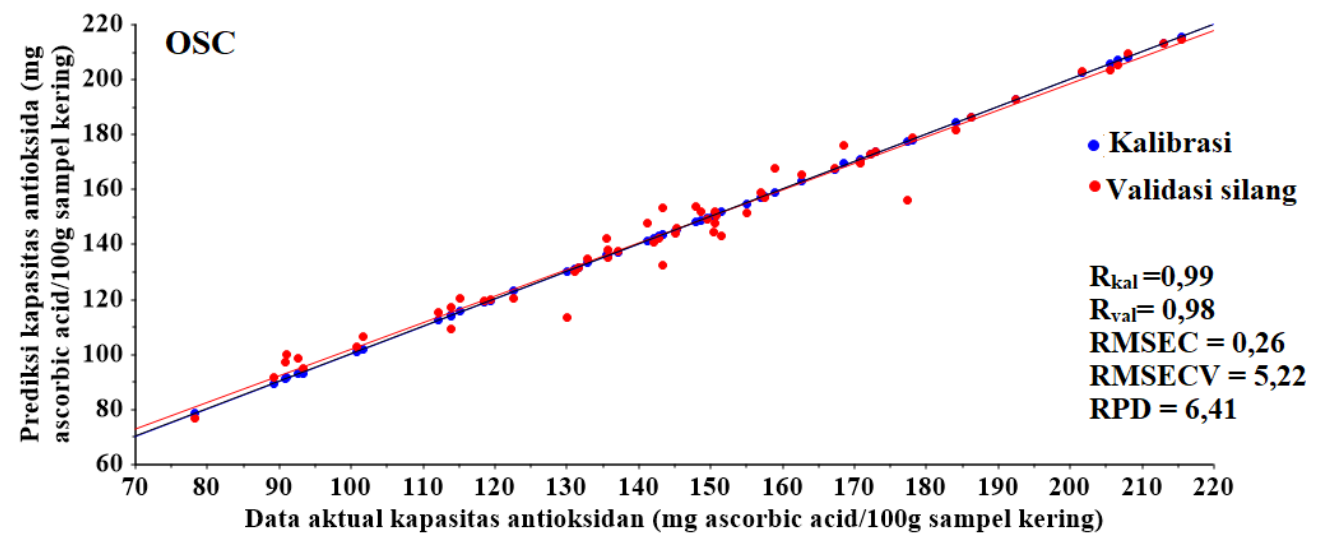

Gambar 4. Scatter plot kalibrasi dan validasi silang kapasitas antioksidan: OSC

Model kalibrasi dengan nilai koefisien korelasi tertinggi untuk parameter total karotenoid diperoleh melalui penerapan metode koreksi OSC. Model kalibrasi dan uji validasi silang untuk total karotenoid dengan OSC berhasil mendapatkan nilai $R_{\text {kal }}$ 0,99; RMSEC 3,54; $R_{\mathrm{cv}}$ 0,97; RMSECV 29,24 dan RPD 5,26. Hal ini sejalan dengan penelitian Saad et al. (2016) yang menyatakan bahwa aplikasi OSC menghasilkan akurasi tertinggi pada pengujian pada TPT, likopen dan kadar asam buah tomat. Pengolahan model kalibrasi dengan penggunaan PLSR dapat mengolah variabel $X$ dan $Y$ secara bersamaan dan diaplikasikan sebagai bentuk prediksi serangkaian bahan organik (Yan-De et al., 2007). Sebaran data model kalibrasi dan uji validasi silang nilai total karotenoid ditampilkan pada Gambar 2.

Aktivitas antioksidan memperoleh tingkat keakuratan dari data original yaitu $0,87\left(R_{\text {kal }}\right), 283,62 \quad$ (RMSEC), $0.84 \quad\left(R_{\text {val }}\right)$, 312,04 (RMSECV) dan 1,90 (RPD). Metode koreksi OSC diterapkan untuk dapat meningkatkan nilai akurasi suatu model. Aktivitas antioksidan dengan penerapan metode koreksi OSC berhasil menurunkan nilai eror dan menghasilkan keakuratan yaitu 0,87 ( $\left.R_{\text {kal }}\right), 278,34$ (RMSEC), 0,84 ( $\left.R_{c v}\right)$, 310,11 (RMSECV) dan 1,91 (RPD).

Model kalibrasi dari spektra original pada kapasitas antioksidan mendapatkan nilai $R_{\text {kal, }}$ RMSEC, $R_{\text {val, }}$ RMSECV dan RPD masing - masing yaitu 0,$67 ; 24,60 ; 0,63$; 26,06 dan 1,28. Metode koreksi OSC berhasil meningkatkan nilai akurasi model dan menghasilkan nilai $R_{k a l}, R M S E C, R_{v a l}$, RMSECV dan RPD masing - masing yaitu 0,$99 ; 0,26 ; 0,98 ; 5,22$ dan 6,41. Peningkatan keakuratan suatu model disebabkan karena noise yang berkurang. Noise dapat terjadi disebabkan oleh adanya kontaminasi cahaya lain, getaran saat scanning sampel atau adanya debu atau kotoran yang menempel pada permukaan sampel. Selain itu, noise dapat juga terjadi karena adanya celah cahaya sehingga radiasi mengenai objek yang lain dan suhu tinggi pada alat (Syahrul et al., 2018).

Sebaran data model kalibrasi dan uji validasi silang aktivitas dan kapasitas antioksidan dengan metode koreksi OSC terlihat pada Gambar 3 dan Gambar 4. Sebaran data yang semakin mendekati garis regresi menandakan model semakin akurat. Scatter plot yang membentuk garis yang menunjukkan pengaruh yang kuat apabila titik - titik sebaran data sangat dekat 
dengan garis regresi yang ditetapkan (Paiman, 2019).

\section{SIMPULAN}

1. Buah cabai rawit varietas 'Manik' dan 'Domba' memiliki kadar air dan kandungan antioksidan tertinggi pada 20 hari setelah bunga mekar (HSBM) dan mengalami penurunan pada saat sudah matang (60 HSBM). Total karotenoid pada buah cabai rawit 'Manik' dan 'Domba' mengalami peningkatan saat matang.

2. Pengukuran kadar air, total karotenoid, dan kandungan antioksidan dapat dilakukan dengan metode non-destruktif dengan menggunakan teknologi Visibel/Near Infrared Spectroscopy (Vis/NIRS). Keakuratan model untuk kadar air, total karotenoid dan antioksidan yaitu $R_{\text {kal }} \geq 0,87, R_{\text {val }} \geq 0,84$, dan RPD $\geq 1,91$.

\section{UCAPAN TERIMAKASIH}

Penulis mengucapkan terima kasih kepada Yusuf Eka Maulana dan Yuda Hadiwijaya yang telah membantu dalam penelitian ini.

\section{DAFTAR PUSTAKA}

Alamar, P.D., Caramês, E.T.S., Poppi, R.J., Pallone, J.A.L., (2016). Quality evaluation of frozen guava and yellow passion fruit pulps by NIR spectroscopy and Chemometrics. Food Res. Int. 85, 209-214. https://doi.org/10.1016/j.foodres.201 6.04.027

Amanto., B.S., Siswanti., Atmaja, A. (2015). Kinetika pengeringan temu giring (Curcuma heyneana Valeton dan van Zijp) menggunakan cabinet dryer dengan perlakuan pendahuluan blanching. J. Teknol. Has. Pertan. VIII, 107-114.

AOAC. (1995). Official Methods of Analysis Association of Official of Analysis Chemist. Association of Official Analytical Chemists. Washington D.C.

Biswas, A.K., Sahoo, J., Chatli, M.K. (2011). A simple UV-Vis spectrophotometric method for determination of $\beta$ carotene content in raw carrot, sweet potato and supplemented chicken meat nuggets. Lwt - Food Sci. Technol. 44,1809-1813.

https://doi.org/10.1016/j.lwt.2011.03. 017

Castro-Concha, L.A., Tuyub-Che, J., MooMukul, A., Vazquez-Flota, F.A., Miranda-Ham, M.L. (2014). Antioxidant capacity and total phenolic content in fruit tissues from accessions of Capsicum chinense Jacq. (Habanero Pepper) at different stages of ripening. Sci. World J. 5. https://doi.org/10.1155/2014/809073

Deepa, N., Kaur, C., George, B., Singh, B., Kapoor, H.C. (2007). Antioxidant constituents in some sweet pepper (Capsicum annuum L.) genotypes during maturity. LWT - Food Sci. Technol. 40, 121-129. https://doi.org/10.1016/j.Iwt.2005.09. 016

Dos Santos, R.F., Gomes-Junior, F.G., Marcos-Filho, J. (2020). Morphological and physiological changes during maturation of okra seeds evaluated through image analysis. Sci. Agric. 77, 1-9. https://doi.org/10.1590/1678992x-2018-0297

Fan, S., Wang, Q., Tian, X., Yang, G., Xia, Y., Li, J., Huang, W. (2020). Nondestructive evaluation of soluble solids content of apples using a developed portable Vis/NIR device. Biosyst. Eng. 193,138-148.

https://doi.org/10.1016/j.biosystemse 
ng.2020.02.017

Getahun, E., Gabbiye, N., Delele, M.A., Fanta, S.W., Gebreslasie, G.M., Maarten Vanierschot. (2020). Effect of maturity on the moisture sorption isotherm of chili pepper (Mareko Fana variety). Heliyon 6 https://doi.org/10.1016/j.heliyon.2020 .e04608

Gómez-García, Rocío, M. del, Ochoa-Alejo, N. (2013). Biochemistry and molecular Biology of carotenoid biosynthesis in chili peppers (Capsicum spp.). Int. J. Mol. Sci. 14, 19025-19053. https://doi.org/10.3390/ijms14091902 5

Hadiwijaya, Y., Kusumiyati, K., Munawar, A.A. (2020a). Prediksi total padatan terlarut buah melon golden menggunakan vis-swnirs dan analisis multivariat. J. Penelit. Saintek 25, 103114.

https://doi.org/10.21831/jps.v25i2.34 487

Hadiwijaya, Y., Kusumiyati, K., Munawar, A.A. (2020b). Penerapan teknologi visible-near infrared spectroscopy untuk prediksi cepat dan simultan kadar air buah melon (Cucumis melo L.) golden. Agroteknika 3, 67-74. https://doi.org/10.32530/agroteknika. v3i2.83

Hamed, M., Kalita, D., Bartolo, M.E., Sastry, S.J. (2019). Capsaicinoids, polyphenols and antioxidant activities of Capsicum annuum: Comparative study of the effect of ripening stage and cooking methods. Antioxidants 8, 364. https://doi.org/10.3390/antiox809036 4

Huang, Y., Lu, R., Chen, K. (2018). Prediction of firmness parameters of tomatoes by portable visible and near-infrared spectroscopy. J. Food Eng. 222, 185198.

https://doi.org/10.1016/j.jfoodeng.20 17.11 .030
Khairiah, Setiasih, I.S., Sukarminah, E., Kusumiyati. (2019). Effect of type and maturity on water content of three varieties of hot chilli (Capsicum frutescens L, Catas, Segana and Domba Variety). IOP Conf. Ser. Mater. Sci. Eng. 506, 1-6. https://doi.org/10.1088/1757899X/506/1/012041

Kusumiyati, Hadiwijaya, Y., Putri, E. I. (2018). Determination of water content of intact sapodilla using near infrared spectroscopy. IOP Conf. Ser. Earth Environ. Sci. 207, 1-7. https://doi.org/10.1088/17551315/207/1/012047

Kusumiyati, Hadiwijaya, Y., Putri, I.E., Mubarok, S., Hamdani, J.S. (2020). Rapid and non-destructive prediction of total soluble solids of guava fruits at various storage periods using handheld near-infrared instrument. IOP Conference Series: Earth and Environmental Science. pp. 1-7. https://doi.org/10.1088/17551315/458/1/012022

Kusumiyati, Hadiwijaya, Y., Putri, I.E., Munawar, A.A. (2021a). Multi-product calibration model for soluble solids and water content quantification in Cucurbitaceae family, using visible/near-infrared spectroscopy. Heliyon 7, e07677. https://doi.org/10.1016/j.heliyon.2021 .e07677

Kusumiyati, K., Hadiwijaya, Y., Putri, I.E., Munawar, A.A., (2021). Enhanced visible/near-infrared spectroscopic data for prediction of quality attributes in Cucurbitaceae commodities. Data Br. 39, 107458. https://doi.org/10.1016/j.dib.2021.10 7458

Kusumiyati, Putri, I.E., Munawar, A.A. (2021b). Model prediksi kadar air buah cabai rawit domba (Capsicum frutescens L.) menggunakan 
spektroskopi ultraviolet visible near infrared. Agro Bali Agric. J. 4, 15-22. https://doi.org/10.37637/ab.v0i0.615

Lai, H., Lim, Y. (2011). Evaluation of antioxidant activities of the methanolic extracts of selected ferns in Malaysia. Int. J. Environ. Sci. Dev. 2, 442-447.

https://doi.org/10.7763/ijesd.2011.v2. 166

Li, H., Pordesimo, L.O., Igathinathane, C., Vinyard, B. (2009). Physical property effects on drying of chile peppers. Int. J. Food Prop. 12, 316-330. https://doi.org/10.1080/10942910701 689796

Lim, Y.Y., Murtijaya, J. (2007). Antioxidant properties of Phyllanthus amarus extracts as affected by different drying methods. LWT - Food Sci. Technol. 40, 1664-1669.

https://doi.org/10.1016/j.Iwt.2006.12. 013

Masdar, Munawar, A.A., Zulfahrizal. (2016). Komparasi metode koreksi spektrum NIRS (De-Trending dan Derivatif ke-2) untuk penentuan kadar air bubuk biji kakao. J. Ilm. Mhs. Pertan. 1, 10591068.

https://doi.org/10.17969/jimfp.v1i1.1 188

Munawar, A.A., Hörsten, D. V, Mörlein, D., Pawelzik, E., Wegener, J.K. (2013). Rapid and non-destructive prediction of mango sweetness and acidity using near infrared spectroscopy, in: Lecture Notes in Informatics (LNI), Proceedings - Series of the Gesellschaft Fur Informatik (GI). pp. 219-222.

Olarewaju, O.O., Bertling, I., Magwaza, L.S. (2016). Non-destructive evaluation of avocado fruit maturity using near infrared spectroscopy and PLS regression models. Sci. Hortic. (Amsterdam). 199, 229-236. https://doi.org/10.1016/j.scienta.2015 .12 .047
Paiman (2019). Teknik analisis korelasi dan regresi ilmu-ilmu pertanian, Pertama. ed. UPY Press.

Pinheiro-santana, H.M., Stringheta, P.C., Brandao, S.C.C., Paez, H.H., Queiroz, V.M.V. de. (1998). Evaluation of total carotenoids, alpha- and beta-carotene in carrots (Daucus carota L.) during home processing. Ciência e Tecnol. Aliment. 18. https://doi.org/10.1590/s010120611998000100009

Putri, I.E., Kusumiyati, Munawar, A.A. (2021). Penerapan algoritma diskriminasi menggunakan metode principal component analysis (PCA) dan Vis-SWNIR spectroscopy pada buah cabai rawit domba berbagai tingkat kematangan. Sintech J. 4, 4046.

https://doi.org/10.31598/sintechjourn al.v4i1.680

Rahmatullah, N. (2018). Karakterisasi morfologi, kandungan karotenoid, dan sekuen gen Ccs pada cabai rawit G1 original type dan mutan G1/M13. Thesis. Universitas Brawijaya

Rusmana, D., Wahyudianingsih, R., Elisabeth, M., Balqis, Maesaroh, Widowati, W. (2017). Antioxidant Activity of Phyllanthus niruri Extract, Rutin and Quercetin. Indones. Biomed. J. 9, 84-90. https://doi.org/DOI: 10.18585/inabj.v9i2.281

Saad, A., Jha, S.N., Jaiswal, P., Srivastava, N., Helyes, L. (2016). Non-destructive quality monitoring of stored tomatoes using VIS-NIR spectroscopy. Eng. Agric. Environ. Food 9, 158-164. https://doi.org/10.1016/j.eaef.2015.1 0.004

Sánchez, M.T., De La Haba, M.J., BenítezLópez, M., Fernández-Novales, J., Garrido-Varo, A., Pérez-Marín, D. (2012). Non-destructive characterization and quality control of intact strawberries based on NIR 
spectral data. J. Food Eng. 110, 102108.

https://doi.org/10.1016/j.jfoodeng.20 11.12.003

Sari, H.P., Purwanto, Y, A., Budiastra, I.W. (2016). Pendugaan kandungan kimia mangga gedong gincu menggunakan spektroskopi inframerah dekat. J. Agritech 36, 294. https://doi.org/10.22146/agritech.165 99

Shao, Y., He, Y. (2008). Nondestructive measurement of acidity of strawberry using Vis/NIR spectroscopy. Int. J. Food Prop. 11, 102-111. https://doi.org/10.1080/10942910701 257057

Sil, K.H., SimHan, Y. (2008). Antioxidant activities of red pepper (Capsicum annuum) pericarp and seed extracts. Int. J. Food Sci. Technol. 43, 1813$1823 . \quad$ https://doi.org/DOI: 10.1111/j.1365-2621.2008.01715.x

Standarisasi Nasional Indonesia. (2019). Cara Uji Makanan dan Minuman (SNI01-02891-1992. Badan Standarisasi Nasional.

Sun, T., $\mathrm{Xu}, \mathrm{Z}$., $\mathrm{Wu}, \mathrm{C} . T .$, Janes, $\mathrm{M}$., Prinyawiwatkul, W., No, H.K. (2007). Antioxidant activities of different colored sweet bell peppers (Capsicum annuum L.). J. Food Sci. 72, 98-102. https://doi.org/10.1111/j.17503841.2006.00245.x

Syahrul., Pratiwi, S., Munawar, A.A. (2018). Prediksi cepat kadar air tanah menggunakan near infrared reflectance spectroscopy, in: Seminar Nasional PERTETA 2018: Mekanisasi, Otomasi Dan Aplikasi ICT Dalam Mendukung Bioindustri Dan Industri Kelapa Sawit Berkelanjutan. Institut Pertanian STIPER, Yogyakarta, pp. 300-308.

Wall, M.M., Waddell, C.A., Bosland, P.W. (2001). Variation in $\beta$-carotene and total carotenoid content in fruits of Capsicum. HortScience 36, 746-749. https://doi.org/10.21273/hortsci.36.4. 746

Wulananggraeni, R., Damanhuri, Purnamaningsih, S.L. (2016). Pengaruh perbedaaan tingkat kemasakan buah pada 3 genotip mentimun (Cucumis sativus L.) terhadap kualitas benih. J. Produksi Tanam, 4, 332-341.

Yan-De, L., Xing-Mao, C., Xu-Dong, S., Yi-Bin, Y. (2007). Non-destructive measurement of pear internal quality indices by visible and near-infrared spectrometric techniques. New Zeal. J. Agric. Res. 50, 1051-1057. https://doi.org/10.1080/00288230709 510385

Zimmer, A.R., Leonardi, B., Miron, D., Schapoval, E., Oliveira, J.R. de, Gosmann, G. (2012). Antioxidant and anti-inflammatory properties of Capsicum baccatum : From traditional use to scientific approach. J. Ethnopharmacol. 139, 228-233. https://doi.org/10.1016/j.jep.2011.11. 005 